\title{
Fate of endocrine-disrupting chemicals in percolating domestic wastewater effluent
}

\author{
C. Ó Súlleabháin, L. W. Gill, B. D. R. Misstear MCIWEM \& P. M. Johnston \\ Department of Civil, Structural and Environmental Engineering, Trinity College Dublin, Dublin 2, Ireland
}

\section{Keywords \\ endocrine-disrupting chemicals; groundwater protection; septic tanks; subsoils; wastewater treatment. \\ Correspondence \\ Bruce Misstear, Department of Civil, Structural and Environmental Engineering, Trinity College Dublin, Dublin 2, Ireland. Email: bmisster@tcd.ie}

doi:10.1111/j.1747-6593.2008.00116.x

\begin{abstract}
Septic tanks and other on-site systems are a common means of disposing domestic wastewater effluent in Ireland. In assessing site suitability, subsoils below the percolation trench have an important role in attenuating pollutants and hence in protecting groundwater. As part of an investigation into the hydraulic performance of treatment systems at four sites in Ireland with different subsoil characteristics, a series of samples were analysed for endocrine-disrupting chemicals (EDCs), including oestrogens, surfactants and organic oxygen compounds. EDCs were found at all four sites, but only at low concentrations (often below those at which their presence could be confirmed) and generally only in samples known to be percolating effluent. Further research should target oestrogen compounds, as these appear to be present in higher concentrations than the other EDCs and also have greater potency.
\end{abstract}

\section{Introduction}

Potential pollution from on-site wastewater discharges is a major concern in Ireland, with respect to both the large number of such systems and the high vulnerability of many of the country's major aquifers. More than onethird of the population is served by small-scale independent systems, usually in rural areas: there are estimated to be more than 350000 septic tank systems currently installed in Ireland [Environmental Protection Agency (EPA) 2000]. In situations where a septic tank installation is not suitable, additional treatment in the form of mechanically aerated systems or filter systems may be used. As part of a wider research programme into the effectiveness of subsoils in treating wastewater effluent discharged from on-site systems, an investigation was carried out into the effectiveness of subsoils for removing endocrinedisrupting chemicals (EDCs). A previous study in Ireland looked at the effects of EDCs in effluents from wastewater treatment plants discharging into rivers (Tarrant et al. 2006), but there has been scant research, both in Ireland and abroad, on the fate of EDCs in effluent from on-site wastewater treatment systems, especially where the effluent percolates through the subsoil before entering the groundwater resource.

The subsoil plays a crucial role in protecting groundwater resources from sewage or other types of pollution (DoELG et al. 1999; Misstear \& Daly 2000). The under- lying bedrock aquifers are characterised by fissure flow, with only limited scope for further attenuation of pollutants (Robins \& Misstear 2000). Where subsoil is thin or absent, there is a high risk of pollution from septic tanks or other pollution sources. The risks to human health may be significant, in that there is a very large number of private well sources in Ireland: a census identified 138000 dwellings with private supplies (Central Statistics Office 2004), the majority of which are likely to be wells. In many cases, these wells have been poorly located with respect to pollution hazards such as septic tanks or farmyards, and they are also poorly constructed, often without a protective sanitary grout seal around the upper well casing (Misstear \& Hynds 2007).

The Irish Environmental Protection Agency has published a guidance manual with the aim of protecting groundwater resources from contamination by domestic wastewater effluent from single houses (EPA 2000). The recommended site assessment procedure, consisting of a desk study followed by an on-site visual trial hole inspection and percolation test, determines the vulnerability of local groundwater resources and identifies receptors potentially at risk. It is recommended that the percolation rate obtained from a standard falling head percolation test (the so-called $T$-value), for subsoils receiving septic tank wastewater effluent, must fall within the specified range of $1 \mathrm{~min}$ per $25 \mathrm{~mm}$ to $50 \mathrm{~min}$ per $25 \mathrm{~mm}$ of water level fall (i.e. $1-50$ ). 
The aim of this research was to provide an insight into the effectiveness of both on-site systems and in situ subsoils with respect to the removal of certain EDCs. This paper presents the results of a series of samples taken and analysed specifically for EDCs from four sites in eastern Ireland, which were being monitored as part of a 3-year research study funded by the EPA into the effectiveness of both septic tank and secondary treatment on-site wastewater systems designed according to the EPA guidelines (Gill et al. 2005, 2007).

\section{EDCs}

Recent years have seen heightened interest into the investigation of a number of compounds that interfere with the normal action of the endocrine system, collectively known as EDCs. An endocrine disrupter is 'an exogenous substance or mixture that alters function(s) of the endocrine system and consequently causes adverse health effects in an intact organism, or its progeny, or (sub)populations' (Damstra et al. 2002). Exposure to elevated levels of environmental oestrogens has been associated with sexual disruption of fish populations, eggshell thinning in bird populations and gonad modification of reptiles. For example, a major research effort was carried out on the effects of wastewater treatment effluent on British fish, which demonstrated oestrogenic effects (Purdom et al. 1994). A recent Irish study on EDCs in the aquatic environment found evidence of endocrine disruption in male brown trout in a river downstream of one wastewater treatment plant, although the study concluded that Irish rivers and lakes do not appear to be at general risk from environmental oestrogens (Tarrant et al. 2006).

\section{EDCs in wastewater effluent}

The aquatic environment acts as a sink for many compounds discharged via the wastewater treatment system, including EDCs. The majority of EDCs associated with domestic wastewater can be grouped into the following generic categories: steroid compounds, surfactants and organic oxygen compounds. Other groups of EDCs, including pesticides and polyaromatic hydrocarbons, are not generally found in significant concentrations in domestic effluent.

Natural steroid oestrogens can be found in sewage effluent generated by women of reproductive age. There are at least six distinct oestrogen hormones but only three are present in significant amounts in the female body: $17 \beta$ oestradiol, oestrone and oestriol. Synthetic oestrogens are also found in wastewater effluent originating from the contraceptive pill or hormone replacement therapy.
According to a survey of 1500 Irish women between the ages of 15 and $64,41 \%$ used the contraceptive pill (VHI 2001). In the United Kingdom, it is reported that about one in three of all females of reproductive age use the contraceptive pill (Delvin 2007).

Surfactants exhibit varying degrees of oestrogenicity and are common in sewage effluent primarily from their use in detergents. The main EDCs of interest are a large number of chemicals collectively known as alkylphenols and their ethoxylates, particularly the nonylphenol compounds, which are used in household detergents and also in other cleaning products, cosmetics and paints. The alkylphenols, octylphenol and nonylphenol, are also used as antioxidants in plastics.

Organic oxygen compounds include dioxins, bisphenols and phthalates. The main compounds of concern in domestic sewage effluent are bisphenol A, which is generated from the production of polycarbonate and epoxy resins and certain phthalates, which are involved in the manufacture of PVC and other resins. These plastics are used in food packaging, tooth fillings, dental materials (and other domestic products), and can leach into the product thereby finding their way into the sewage effluent.

\section{Fate of EDCs in effluent from on-site systems}

Wastewater effluent produced in the house initially passes into the septic tank where sedimentation of the solids occurs. Here, the most significant mechanism of EDC removal is adsorption to solids, which settle as sludge. Studies have shown that significant EDC removal occurs in the sludge at wastewater treatment works (Ying et al. 2002), but few studies have looked at on-site systems. One study on the night soil process in Japan (which is similar to a septic tank) showed that the majority of steroid oestrogens were accumulated in the sludge and not passed forward in the aqueous phase (Takigami et al. 2000). Concentrations of $17 \beta$-oestradiol, for example, were 5000 times more concentrated in the sludge than in the effluent from the treatment plant. Research into on-site wastewater disposal in Cape Cod, MA, identified bisphenol A concentrations in the septic tank effluent as high as $1 \mu \mathrm{g} / \mathrm{L}$ (Rudel et al. 1998) with oestrone in the range $49-74 \mathrm{ng} / \mathrm{L}$ and $17 \beta$-oestradiol in the range 16-19 $\mathrm{ng} / \mathrm{L}$ (Swartz et al. 2006).

Many on-site treatment systems now involve packaged secondary treatment systems, which are based on the same processes used in the large-scale municipal treatment works. In secondary treatment processes, there are high concentrations of aerobic bacteria and other microorganisms. Here, EDCs can be adsorbed onto the solids but can also be degraded biologically or chemically and in some cases volatilised due to the aeration required. 
Studies have also shown that the removal efficiency of hydrophobic compounds is strongly related to solids retention time (SRT) in biological treatment processes, indicating accumulation of the compound on biosolids (Strenn et al. 2003). Several studies have indicated that both biodegradation and sorption are important in the removal of EDCs in wastewater treatment plants and also indicated that oestrone often remained the most persistent steroid oestrogen in the final effluent with concentrations up to $70 \mathrm{ng} / \mathrm{L}$ (Ternes et al. 1999). This was also concluded by another study ( $\mathrm{D}^{\prime}$ Ascenzo et al. 2002) that found oestrone to be the most resistant to decomposition in wastewater treatment processes compared with the other natural oestrogens.

In terms of surfactants, the alkylphenols are mainly removed by bacterial degradation in secondary processes, suggesting that such EDCs would be expected to pass through the septic tank phase relatively unchanged, which is of relevance to on-site systems that only involve a septic tank. Many of the alkylphenols are degraded to more hydrophobic compounds, which will then adsorb to particulates, thereby finding their way into the sludge. The organic oxygen compounds, phthalates and bisphenol A have been shown to be easily removed in aerobic secondary treatment processes (Staples et al. 1998).

\section{Treatment within the subsoil}

Further removal or degradation of organic, chemical and biological pollutants, which have passed through the onsite process units, can occur within the subsoil. Most EDCs are lipophilic and hence are likely to sorb onto soil particulates. In unsaturated soil, there will also be further aerobic microbiological and chemical degradation of the compounds. For example, Ying \& Kookana (2005) documented rapid and significant degradation of five EDCs under aerobic conditions while only one compound showed evidence of degradation under anaerobic conditions.

A few studies have looked at domestic effluent being discharged within the subsoil in connection with soil aquifer treatment (SAT) and aquifer storage and recovery (ASR), particularly for reuse of grey water or the direct injection of wastewater (Masters et al. 2004). For example, the effect of SAT of secondary-treated effluent was assessed on 13-year-old percolation fields using $17 \beta$-oestradiol, oestriol and testosterone, which revealed that only $17 \beta$-oestradiol was picked up (at concentrations $<1.8 \mathrm{ng} / \mathrm{L}$ ) in the shallow lysimeters ( $1.5 \mathrm{~m}$ depth) in the soil (Mansell \& Drewes 2004). Oestriol and testosterone were not found at the detection limit of $0.6 \mathrm{ng} / \mathrm{L}$, which was attributed to the effects of adsorption and bioactivity.

\section{Study sites and methods}

\section{Sites and instrumentation}

The four study sites are located in the east of Ireland, in areas with glacial till subsoils. The sites were selected to provide contrasting subsoil percolation characteristics (as determined by the $T$-test), where effluent was discharged following either primary (septic tank) or secondary (peat

filter) treatment systems:

Site 1: septic tank effluent into subsoil with a $T$-value of 15.

Site 2: secondary-treated effluent into subsoil with a $T$-value of 29.

Site 3: septic tank effluent into subsoil with a $T$-value of 33 .

Site 4: secondary-treated effluent into subsoil with a T-value of 52 .

The secondary treatment system, preceded by a twochamber septic tank, installed on Sites 2 and 4 was a Puraflo ${ }^{\circledR}$ system produced by Bord na Móna. Puraflo ${ }^{\circledR}$ (Newbridge, Ireland) is a peat-based biofiltration system for the treatment of septic tank effluent.

The effluent from all four sites was distributed to percolation trenches, which were built to EPA specifications (EPA 2000). Each percolation trench was $20 \mathrm{~m}$ long, $800 \mathrm{~mm}$ deep and $450 \mathrm{~mm}$ wide, in which a $110-\mathrm{mm}$ diameter pipe was set in gravel, with its invert about $250 \mathrm{~mm}$ above the base of the trench (Figs 1 and 2).

Automatic samplers and flow monitors were installed downstream of the septic tanks and secondary treatment system to obtain a profile of the effluent entering the percolation trenches. Suction lysimeters were installed along the length of the percolation trenches to collect soil moisture samples for the analysis of some of the characteristic constituents of domestic wastewater effluent [chemical oxygen demand (COD), $\mathrm{NO}_{3}, \mathrm{NO}_{2}, \mathrm{NH}_{4}, \mathrm{PO}_{4}, \mathrm{Cl}$ and enteric bacteria]. The lysimeters were installed in groups of three corresponding to depths of $0.3,0.6$ and $1.0 \mathrm{~m}$ below the base of the percolation trenches (Fig. 1), and at three distances along each trench $(0,10$ and $20 \mathrm{~m}$, as illustrated in Fig. 3). In all cases, the depth to groundwater was greater than the maximum lysimeter depth of $1.0 \mathrm{~m}$ below the base of the percolation trenches. Rainfall volume, evapotranspiration and chloride concentration were also analysed to determine the effect of dilution on the system (Gill et al. 2007). Tensiometers were installed to monitor the soil moisture pressure below the percolation area.

\section{Sampling for EDCs}

In total, 42 samples were taken for EDC analyses. The EDC samples were collected towards the end of each respective trial (12 months in the case of Sites 1 and 2; 9 


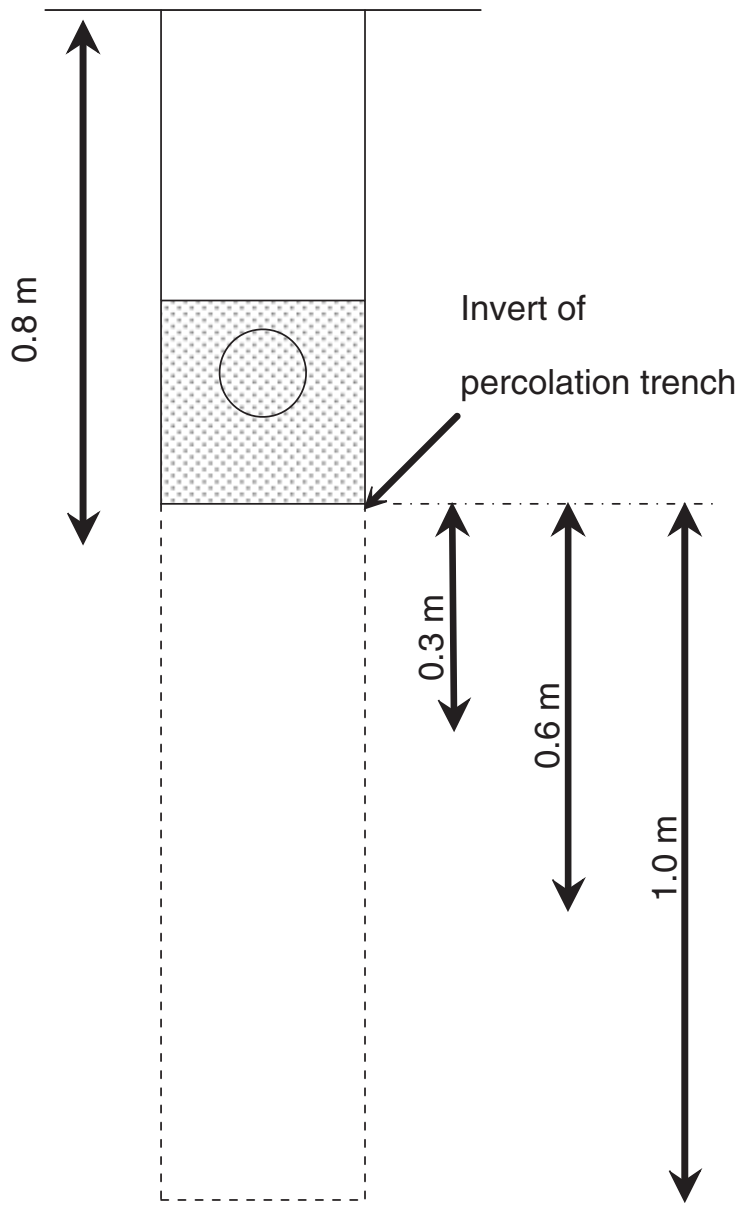

Fig. 1. Cross section of percolation trench and typical lysimeter sampling depths.

months for Sites 3 and 4). One percolation trench was chosen as representative of the percolation area on each site (from the previous sampling results), and samples at all three locations and all three depths in the subsoil were taken. The samples from the subsoil were taken from the suction lysimeters, which were put under pressure the night before (under a suction of 50 cbar) and samples collected the next day. Samples of the septic tank and Puraflo ${ }^{\mathbb{B}}$ effluent were comprised of discrete hourly samples taken over the $24 \mathrm{~h}$ preceding lysimeter sampling, which were then mixed to provide a composite sample. All samples were stored in $1 \mathrm{~L}$ glass jars.

The samples were analysed by gas chromatographymass spectrometer (GC-MS) separation techniques. The following five EDCs were targeted for analysis based on their prevalence in domestic wastewater, variety in terms of source and also their likely persistence through the unit treatment processes and thus levels in the effluent:

- Natural oestrogens: oestrone, 17 $\beta$-oestradiol, oestriol.

- Organic oxygen compound: bisphenol A.

- Surfactants: nonylphenol.

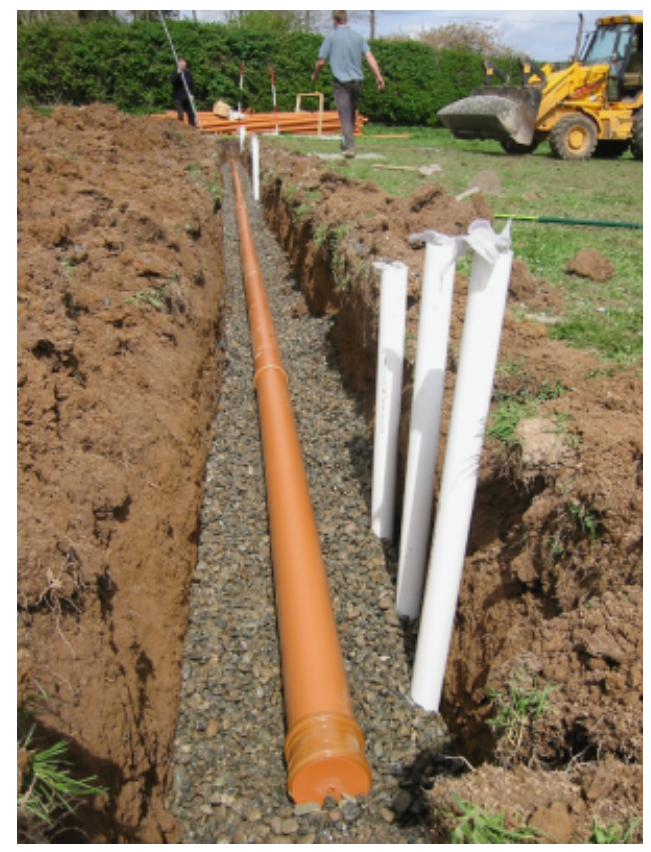

Fig. 2. Construction of percolation trench. Note white guide tubes for installation of lysimeters.

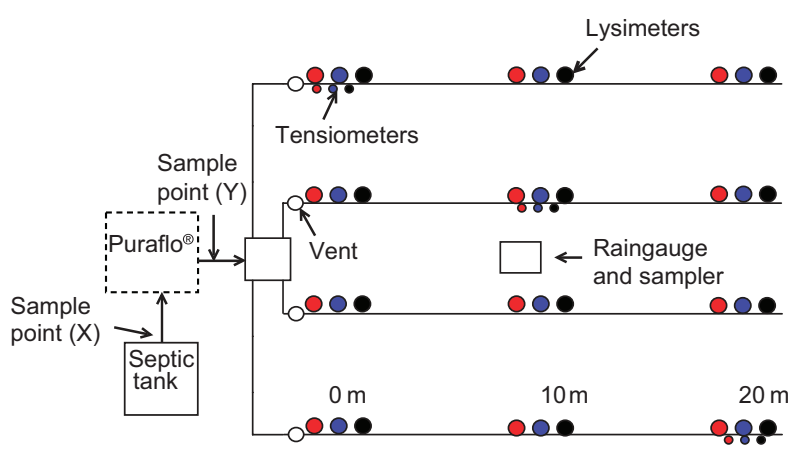

Fig. 3. Plan of percolation area showing instrumentation layout.

Preconcentration of samples was necessary because of limitations in the sensitivity of the instrumental techniques. GC-MS analysis was then carried out on the extracts. The effective limit of detection for the five target species after preconcentration was oestrone $(2 \mu \mathrm{g} / \mathrm{L}), 17 \beta$ oestradiol $(2 \mu \mathrm{g} / \mathrm{L})$, oestriol $(20 \mu \mathrm{g} / \mathrm{L})$, bisphenol A ( $20 \mathrm{ng} / \mathrm{L})$ and nonylphenol $(20 \mathrm{ng} / \mathrm{L})$. In addition to the five target species, mass spectrometric determination of all chromatographic peaks was carried out, allowing identification of other endocrine-disrupting compounds.

\section{Results}

The results of the EDC analyses from the four sites are summarised in Table 1. 


\section{Site 1}

At Site 1, where effluent was discharged directly to the percolation trenches without secondary treatment, chemical and microbiological sampling showed that the effluent had reached all positions along the trenches, owing to extensive development of a low-permeability biomat at the base of each trench (Ó Súilleabháin 2004; Gill et al. 2005). The subsoil was characterised as a sandy CLAY and thus contained a relatively high proportion of clay compared with the other sites. The only EDC that was detected both in the effluent and at all sample positions was octylphenol at levels of $\sim 50 \mathrm{ng} / \mathrm{L}$ (Table 1). Octylphenol is a constituent in household detergents and other cleaning products, which would be used in relatively high quantities on this site, because the business of the premises is a livery stable. The lack of oestrogens detected in either the effluent or out in the percolation area is not that surprising considering that the majority of inhabitants and workers in the stables at the time were male.

\section{Site 2}

The percolation area was receiving secondary-treated effluent from the peat filter, and the subsoil was characterised as a sandy SILT with slower percolation characteristics than Site 1. During the 12-month sampling period for nitrogen, phosphorus and other parameters, it was shown that only the lysimeters at the $0 \mathrm{~m}$ positions were receiving the treated effluent, while the remainder were sampling only normal soil moisture. The restricted development of the biomat here is attributed to the lower organic concentrations in the secondary-treated load.

No oestrogens were found to occur at the detectable level in either the septic tank effluent or the secondarytreated effluent. However, levels of oestrogens $(\sim 2.0 \mu \mathrm{g} /$ L) were found in the percolation area at sampling points both where the effluent was known to have reached (at the beginning of the trench) and also at the $20 \mathrm{~m}$ point where effluent had not reached (Table 1). The effluent that was sampled at the beginning of the trench may have been discharged from the secondary treatment unit

Table 1 EDC results

\begin{tabular}{|c|c|c|c|c|c|c|c|c|c|c|}
\hline & \multirow[b]{2}{*}{ STE (SE) } & \multicolumn{3}{|c|}{$0 \mathrm{~m}$ location } & \multicolumn{3}{|c|}{$10 \mathrm{~m}$ location } & \multicolumn{3}{|c|}{20 m location } \\
\hline & & $0.3 \mathrm{~m}$ & $0.6 \mathrm{~m}$ & $1.0 \mathrm{~m}$ & $0.3 \mathrm{~m}$ & $0.6 \mathrm{~m}$ & $1.0 \mathrm{~m}$ & $0.3 \mathrm{~m}$ & $0.6 \mathrm{~m}$ & $1.0 \mathrm{~m}$ \\
\hline \multicolumn{11}{|l|}{ Site 1} \\
\hline Octylphenol & $?$ & $レ$ & $レ$ & $レ$ & $\boldsymbol{V}$ & 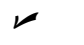 & $レ$ & $\boldsymbol{V}$ & $レ$ & $レ$ \\
\hline \multicolumn{11}{|l|}{ Site 2} \\
\hline Oestrone & & $\boldsymbol{}$ & & & & & & $\boldsymbol{\nu}$ & $\boldsymbol{\nu}$ & $\boldsymbol{\nu}$ \\
\hline $17 \beta$-oestradiol & & レ & & & & & & レ & $レ$ & レ \\
\hline Ethynyloestradiol & & $\nu$ & & & & & & $\boldsymbol{\nu}$ & $\boldsymbol{\nu}$ & $\boldsymbol{\nu}$ \\
\hline Diethylstilbestrol & & レ & & & & & & $\boldsymbol{V}$ & & \\
\hline Octylphenol & $?$ ??) & & & & & & & & & \\
\hline Butylphenol & & & & & $\boldsymbol{V}$ & & & & & \\
\hline Ethylphenol & ? (?) & $?$ & & & & & & & & \\
\hline \multicolumn{11}{|l|}{ Site 3} \\
\hline Ethynyloestradiol & & & & & $?$ & & & & & \\
\hline Diethylstilbestrol & & & & & & $?$ & & & & \\
\hline Octylphenol & & $?$ & $?$ & $?$ & $?$ & & & & & \\
\hline Butylphenol & & $?$ & $?$ & & & & & & & \\
\hline Nonylphenol & & & & & & & & & $?$ & \\
\hline \multicolumn{11}{|l|}{ Site 4} \\
\hline Oestrone & レ & & & $\nu$ & & & & & & \\
\hline $17 \beta$-oestradiol & $\nu$ & & $\boldsymbol{}$ & $\nu$ & & & & & & \\
\hline Diethylstilbestrol & $\nu$ & & & $?$ & & & & & & \\
\hline Bisphenol A & & & & & $?$ & & & & & \\
\hline Octylphenol & (?) & & & & & & & & & \\
\hline Butylphenol & & & $\boldsymbol{\nu}$ & 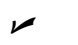 & & & & & & \\
\hline Nonylphenol & & & $?$ & & & & & & & \\
\hline Ethylphenol & (?) & & & & & & & & & \\
\hline
\end{tabular}

$\boldsymbol{V}=$ compound present at or above the limit of detection following preconcentration of sample. Note that the detection limits for the five target species (after preconcentration) were oestrone ( $2 \mu \mathrm{g} / \mathrm{L}), 17 \beta$-oestradiol $(2 \mu \mathrm{g} / \mathrm{L})$, oestriol $(20 \mu \mathrm{g} / \mathrm{L})$, bisphenol A ( $20 \mathrm{ng} / \mathrm{L})$ and nonylphenol $(20 \mathrm{ng} / \mathrm{L})$.

$?=$ mass spectral analysis suggested presence of compound, but at levels below the limits of detection following preconcentration (and therefore could not be confirmed as present).

STE, septic tank effluent; SE, secondary effluent; EDC, endocrine-disrupting chemical. 
several days before the sampling date (because it would take some time to percolate down to the sampling depths) compared with those samples collected at the septic tank and secondary treatment locations. Hence, the subsoil EDC values may be representative of conditions several days earlier, at a time when the production of oestrogens was higher. A much longer and more frequent sampling study would be required to gain a full picture of the processes. The results obtained at the $20 \mathrm{~m}$ sampling points, however, must have been generated from a source at the surface rather than from the treatment system. Several animals (dogs, pigs and wildfowl) had continual access to the area and could have urinated on the surface, which could then have percolated down into the subsoil. The occurrence of ethynloestradiol at these sampling positions, however, is confusing because it is a synthetic oestrogen. Re-analysis of the tandem MS data showed that this could have been confused with another oestrogen or possibly a phytoestrogen.

There is also evidence of octylphenol $(<20 \mathrm{ng} / \mathrm{L})$ in the effluent but no other traces were found in the percolation area suggesting further degradation of the EDC, probably in the biomat. An isolated incidence of butylphenol is likely to be due to some analytical error/contamination. Traces of ethylphenol were discovered in the septic tank and secondary-treated effluent, and at the shallowest depth in the subsoil. Phenol and its derivatives are basic functional units of a wide variety of synthetic organic pollutants including pesticides, and thus their presence can indicate sources associated with chemicals of everyday household or outdoor use.

\section{Site 3}

Site 3 was receiving septic tank effluent, which was discharged into subsoil described as gravely clayey SAND, with slower percolation characteristics than either Site 1 or Site 2. Analyses of the chemical and microbiological parameters revealed that, by the end of the 9-month trial, lysimeters at the first sampling location together with the shallowest lysimeters at the $10 \mathrm{~m}$ location appeared to be receiving the effluent.

The results for Site 3 (Table 1) did not detect EDCs in the septic tank effluent, nor is there firm evidence of EDCs in the percolation area. However, there is some evidence of ethynyloestradiol (component of the contraceptive pill) at the $10 \mathrm{~m}$ sampling point which, at that time, would have been receiving the largest volume of effluent due to the progressive development of the biomat. There is also evidence of octylphenol and butylphenol in subdetection limit concentrations.

\section{Site 4}

The subsoil at Site 4 was characterised as gravely clayey SAND, with the slowest percolation characteristics of all four sites. The chemical and microbiological data for this site showed that the (secondary treated) effluent only reached the $0 \mathrm{~m}$ position on all trenches. The septic tank effluent was found to contain detectable concentrations of the oestrogens oestrone, $17 \beta$-oestradiol and diethylstilbestrol. Oestrone and $17 \beta$-oestradiol (at concentrations of low $\mu \mathrm{g} / \mathrm{L})$ were also positively detected at the $0 \mathrm{~m}$ sampling location (at depths of 0.6 and $1 \mathrm{~m}$, see Table 1 ). It is perhaps surprising that such concentrations are passing through both the septic tank and the peat filter, although Site 4 did have the highest number of female residents compared with the other sites studied.

The alkylphenol results were inconclusive due to the limit of detection restrictions (because of small sample volumes available for analysis), with traces of octylphenol in the secondary effluent and nonylphenol in the subsoil at the $0 \mathrm{~m}$ location, where the effluent was known to be percolating. There were, however, concentrations of butylphenol detected in the subsoil in a lysimeter at $1 \mathrm{~m}$ depth. Butylphenol has been shown to have oestrogen-like properties and is widely used as an intermediate in the manufacture of varnish and lacquer resins, as an antioxidant and as a motor oil additive, and therefore can enter the environment through a number of routes.

The only slight indication of bisphenol A on any of the sites was at a position on this site where the effluent was known not to have percolated, and so the validity of this result has to be questioned.

\section{Discussion}

From the results obtained, it is clear that the EDCs selected for this study are absent at the detection levels achieved for the majority of samples tested. Thus there are only limited data available on which to compare sites or treatment systems.

There appeared to be no discernable difference in the quality of the effluent according to the length of time the sites had been established; Sites 1 and 2 had been established for 12 months compared with 9 months for Sites 3 and 4. There was also no particular evidence of any degradation of EDCs with depth in the subsoil, with the exception possibly of the oestrogens at Site 2 . In fact, the results for both oestrogens and alkylphenols sometimes indicate EDCs at the deeper sampling depths but not in the shallower subsoil above, indicating perhaps the sporadic nature of production and disposal of such EDCs (particularly oestrogens). 
There does seem to be a correlation between the composition of the households and the particular EDCs found in the effluent: for example, the relatively high level of surfactants on Site 1, which is a livery stable, and the relatively high level of oestrogens in Site 4, which has the largest number of female occupants. In relation to secondary treatment, the results from Site 4 suggested that oestrone and $17 \beta$-oestradiol had been reduced to below the limit of detection by the secondary treatment process. However, oestrogens were found at detectable concentrations 'downstream' in the subsoil, indicating that these oestrogens must have previously passed through the peat filter.

\section{Fate and behaviour of specific EDCs detected in this study}

The fate and behaviour of EDCs is mainly influenced by their physiochemical properties, and the majority of EDCs tend to favour adsorption onto solid surfaces or into biota (Birkett \& Lester 2002). Hence, in general it would be expected that all of the target analytes would be immediately trapped in the humic material or natural organic matter in the sample.

Regarding the oestrogens, a surprising result from the study was that oestriol was not detected in any of the sites even though its octanol/water partition coefficient is lower than that for both oestrone and $17 \beta$-oestradiol (Lai et al. 2000), making it less susceptible to adsorption to organic materials in the septic tanks and secondary processes. The reason for this may be its higher analytical detection limit $(20 \mu \mathrm{g} / \mathrm{L})$ compared with the other oestrogens. However, this may also indicate that it is more susceptible to aerobic degradation as shown in other studies whereby oestrone is commonly the most persistent of the oestrogens after secondary treatment (Ternes et al. 1999; D'Ascenzo et al. 2002). In such studies on secondary-treated effluent the highest levels to which oestrone has been detected is of the order of 100-200 ng/L, a concentration 10 times lower than the present study was able to detect. It should also be noted that the other oestrogens are normally found at even lower levels ( $10 \mathrm{ng} / \mathrm{L}$, for example) and that out in the subsoil, previous studies have only detected samples (if detected at all) generally in the range $<10 \mathrm{ng} / \mathrm{L}$ (Mansell $\&$ Drewes 2004; Snyder et al. 2004). Where oestrogens have been detected on these sites, they are of relatively high concentrations with oestrone $(\sim 2 \mu \mathrm{g} / \mathrm{L})$ and $17 \beta$-oestradiol $(\sim 2 \mu \mathrm{g} / \mathrm{L})$. Ethynylestradiol, a component of the contraceptive pill, was shown to be present in Sites 2 and 3. This EDC is known to display a much slower degradation halflife than the natural oestrogens (Ying et al. 2003), and so would be expected to be present in the subsoil even if the natural oestrogens had been long degraded.

It is interesting that the oestrogens were only detected in relatively high concentrations in the subsoil on the two sites receiving secondary-treated effluent (Sites 2 and 4). This may be due to the higher hydraulic loading on the subsoil and the lower organic concentrations in such effluent compared with the septic tank effluent, which has been shown to develop a much more extensive biomat.

The organic oxygen compound bisphenol $\mathrm{A}$, which is used in food packaging and other domestic products, was chosen for this study as it is known to find its way into domestic sewage effluent. Previous research (Rudel et al. 1998) has found concentrations in the septic tank effluent as high as $1 \mu \mathrm{g} / \mathrm{L}$, although bisphenol $\mathrm{A}$ is much less potent as an EDC compared with the oestrogens (Perez et al. 1998). Laboratory experiments on secondary-treated effluent have found bisphenol A at concentrations of 110-180 ng/L (Cordy et al. 2004). In the present study, however, no bisphenol A was detected in any of the effluents or after passing through the subsoil matrix on the sites (down to a detection limit of $20 \mathrm{ng} / \mathrm{L}$ ), indicating that it is possibly not of concern for typical on-site effluents produced in Ireland. The organic oxygen compounds, phthalates and bisphenol A have been shown to be easily removed in aerobic secondary treatment processes (Staples et al. 1998), but this was not possible to verify because none were detected in any septic tank effluent.

In terms of surfactants, previous aerobic degradation experiments (Ying et al. 2003) have shown that nonylphenol degraded quickly, whereas octylphenol showed absolutely no degradation. There seems to be some evidence of this in the current study, with octylphenol being commonly found in several instances out in the percolation area, but only one possible trace of nonylphenol (well below the limits of detection) on Site 4 .

\section{Conclusions}

(1) This initial study has been useful in showing both the levels of EDCs that should be expected from such on-site effluent in Irish households, and some of the removal processes as they pass through typical treatment units and down through the subsoil towards the groundwater.

(2) The results obtained from the four sites have indicated the presence of four of the five target analytes in some of the samples tested. The analytes are only present at very low concentrations, often below the reliable detection limit (with preconcentration) and generally only in samples known to be percolating effluent. 
(3) The results do not indicate that the analytes in question, where present in the original wastewater, are removed while passing through the subsoil, and as such the study cannot make any definitive conclusions about the ability of the subsoil to reduce these EDCs.

(4) There is evidence that some of the oestrogens have been detected in relatively high concentrations in the subsoil compared with other studies, particularly on the two sites with secondary treatment.

(5) However, the levels of the other targeted EDCs (organic oxygen compounds and surfactants) from on-site treatment systems are very low, particularly for bisphenol A (down to limits of $20 \mathrm{ng} / \mathrm{L}$ ) and as such probably pose little threat to groundwater sources.

(6) Previous studies have shown that alkylphenol surfactants have a lower endocrine disruption potency than bisphenol A, and also that bisphenol $\mathrm{A}$ has a much lower potency than the oestrogen, $17 \beta$-oestradiol.

(7) Therefore, a major target for future research should be the oestrogen compounds, which seem to be present in higher concentrations than the other compounds and also have a higher potency. Future research should be designed to improve detection limits by producing larger sampling volumes, and enhanced methods of analysis such as liquid chromatography-tandem mass spectrometry techniques.

(8) Ideally, such research should enable samples to be taken regularly over periods of several months in order to catch variations in concentration profiles.

\section{Acknowledgements}

This research was carried out as part of the Environmental Research Technological Development and Innovation Programme under the Productive Sector Operational Programme 2000-2006. The programme was financed by the Irish Government under the National Development Plan 2000-2006. It was administered on behalf of the Department of the Environment, Heritage and Local Government by the Environmental Protection Agency, which has the statutory function of co-ordinating and promoting environmental research.

The authors would like to thank Dr. Fiona Regan and Anne Moran from the School of Chemical Sciences, Dublin City University, for the analysis of the samples.

\section{References}

Birkett, J.W. and Lester, J.N. (2002) Endocrine Disrupters in Wastewater and Sludge Treatment Processes. IWA Publishing and Lewis Publishers, CRC Press LLC, London, UK.

Central Statistics Office. (2004) Census 2002 Report, Volume 13 - Housing. Government of Ireland, Dublin, Ireland.
Cordy, G.E., Dunran, N.L., Bouwer, H., Rice, R.C., Furlong, E.T., Zaugg, S.D., Meyer, M.T., Barber, L.B. and Kolpin, D.W. (2004) Do Pharmaceuticals, Pathogens and Other Organic Waste Water Compounds Persist When Waste Water is Used for Recharge? Ground Water Monit. Remediat., 24 (2), 58-69.

Damstra, T., Barlow, S., Bergman, A., Kavlock, R. and Van der Kraak, G. (2002) Global Assessment of the State-of-the-Science of Endocrine Disrupters. World Health Organisation, Geneva, Switzerland.

D’Ascenzo, G., Di Corcia, A., Gentili, A., Mancini, R., Msatropasqua, R., Nazzari, M. and Samperi, R. (2002) Fate of Natural Estrogen Conjugates in Municipal Sewage Transport and Treatment Facilities. Sci. Total Environ., 302, 199-209.

Delvin, D. (2007) Is the pill popular? [online] http://www. netdoctor.co.uk/sex_relationships/facts/contraceptivepills.htm [accessed 4 March 2007].

Department of the Environment and Local Government, Environmental Protection Agency and Geological Survey of Ireland (DoELG) . (1999) A Scheme for the Protection of Groundwater. Geological Survey of Ireland, Dublin.

Environmental Protection Agency (EPA ). (2000) Wastewater Treatment Manuals - Treatment Systems for Single Houses. EPA, Wexford.

Gill, L.W., O'Súlleabháin, C., Johnston, P.M. and Misstear, B.D.R. (2005) An Investigation into the Performance of Subsoils and Stratified Sand Filters for the Treatment of Wastewater from On-Site Systems - Synthesis Report. Environmental Protection Agency, Wexford, $51 \mathrm{pp}$.

Gill , L.W., O'Súilleabháin, C., Misstear, B.D.R. and Johnston, P.M. (2007) The Treatment Performance of Different Subsoils in Ireland Receiving On-Site Wastewater Effluent. J. Environ. Qual., 36, 1843-1855.

Lai, K.M., Johnson, K.L., Scrimshaw, M.D. and Lester, J.N. (2000) Binding of Waterborne Steroid Estrogens to Solid Phases in River and Estuarine Systems. Environ. Sci. Technol., 34, 3890-3894.

Mansell, J. and Drewes, J.E. (2004) Fate of Steroidal Hormones During Soil-Aquifer Treatment. Ground Water Monit. Remediat., 24 (2), 94-101.

Masters, R.W., Verstraeten, I.M. and Heberer, T. (2004) Fate and Transport of Pharmaceuticals and Endocrine Disrupting Compounds During Ground Water Recharge. Ground Water Monit. Remediat., 24 (2), 54-57.

Misstear, B.D.R. and Daly, D. (2000) Groundwater Protection in a Celtic Region: The Irish Example. In Robins, N.S. and Misstear, B.D.R. (eds). Groundwater in the Celtic Regions: Studies in Hard Rock and Quaternary Hydrogeology, pp. 53-65. Geological Society, London.

Misstear, B.D.R. and Hynds, P. (2007) Research into the Health Risks Associated with Private Well Supplies in Ireland. Geo. Surv. Ireland Groundwater Newslett., 46, 27-30.

Ó Súilleabháin, C. (2004) The attenuation capacity of different subsoils receiving domestic wastewater effluent. Unpublished $\mathrm{PhD}$ Thesis, University of Dublin, Trinity College.

Perez, P., Pulgar, R., Olea-Serrano, F., Villabos, M., Rivas, A., Metzler, M., Pedraza, V. and Olea, N. (1998) The Estrogenicity of Bisphenol A-Related Diphenylalkanes with Various 
Substitutes at the Central Carbon and the Hydroxyl Groups. Environ. Health Perspect., 106 (3), 167-174.

Purdom, C.E., Hardiman, P.A., Bye, V.J., Eno, N.C., Tyler, C.R. and Sumpter, J.P. (1994) Estrogenic Effects of Effluents from Sewage Treatment Works. Chem. Ecol., 8, 275-285.

Robins, N.S. and Misstear, B.D.R. (2000) Groundwater in the Celtic Regions. In Robins, N.S. and Misstear, B.D.R. (eds). Groundwater in the Celtic Regions: Studies in Hard Rock and Quaternary Hydrogeology, pp. 5-17. Geological Society, London.

Rudel, R.A., Melly, S.J., Geno, P.W., Sun, G. and Brody, J.G. (1998) Identification of Alkylphenols and other Estrogenic Phenolic Compounds in Wastewater, Septage and Groundwater on Cape Cod, Massachusetts. Environ. Sci. Technol., 32, 861-869.

Snyder, S.A., Leising, J., Westerhoff, P., Yoon, Y., Marsh, H. and Vanderford, B. (2004) Biological and Physical Attenuation of Endocrine Disruptors and Pharmaceuticals: Implications for Water Reuse. Ground Water Monit. Remediat., 24 (2), 108-118.

Staples, C.A., Dorn, P.B., Klecka, G.M., O'Block, S.T. and Harris, L.R. (1998) A Review of the Environmental Fate, Effects and Exposures of Bisphenol A. Chemosphere, 36, 2149-2173.

Strenn, B., Clara, M., Gans, O. and Kreuzinger, N. (2003) Occurrence and Elimination of Selected Endocrine Disrupting Chemicals in Waste Water Treatment. In Proceedings of the 3 rd International Conference on Pharmaceuticals and Endocrine Disrupting Chemicals in Water. NGWA, Minneapolis, MN.
Swartz, C.H., Reddy, S., Benotti, M.J., Yin, H., Barber, L.B., Brownawell, B.J. and Rudel, R.A. (2006) Steroid Estrogens, Nonylphenol Ethoxylate Metabolites, and other Wastewater Contaminants in Groundwater Affected by a Residential Septic System on Cape Cod, MA. Environ. Sci. Technol., 40, 4894-4902.

Takigami, H., Taniguchi, N., Matsuda, T., Yamada, M. and Matsui, S. (2000) The Fate and Behaviour of Human Estrogens in Night Soil Treatment Processes. Water Sci. Technol., 42, 7-8.

Tarrant, H., Lllewellyn, N., Lyons, A., Tattersall, N., Wylde, S., Mouzakitis, G., Maloney, M. and McKenzie, C. (2006) Endocrine Disrupters in the Aquatic Environment - Synthesis Report. Environmental Protection Agency, 16 pp.

Ternes, T.A., Stumpf, M., Mueller, J., Haberer, K., Wilken, R.D. and Servos, M. (1999) Behaviour and Occurrence of Estrogens in Municipal Sewage Treatment Plants. Investigations in Germany, Canada and Brazil. Sci. Total Environ., 225, 81-90.

VHI. (2001) New contraceptive pill for women [online]. http:// www.vhi.ie/news/n030401a.jsp [accessed 4 April 2001].

Ying, G., Rai, S.K. and Ying-Jun, R. (2002) Occurrence and Fate of Hormone Steroids in the Environment. Environ. Int., 28, 545-551.

Ying, G., Kookana, R.S. and Dillon, P. (2003) Sorption and Degradation of Five Endocrine Disrupting Chemicals in Aquifer Material. Water Res., 37, 3785-3791.

Ying, G.G. and Kookana, R.S. (2005) Sorption and Degradation of Estrogen-Like-Endocrine Disrupting Chemicals in Soil. Environ. Toxicol. Chem., 24, 2640. 